\title{
3. Personal Relationships between Co-buried Individuals in the Central European Early Bronze Age
}

\author{
KATHARINA REBAY-SALISBURY
}

Rebay-Salisbury, K. 2018. Across the Generations: The Old and the Young in Past Societies. AmS-Skrifter 26, 35-48, Stavanger. ISSN 0800-0816, ISBN 978-82-7760-181-6.

People were usually buried in single, individual graves in Early Bronze Age Austria and the surrounding areas, but there are some exceptions. In burials of two or more people, it is often the way that bodies were placed in relation to each other that suggests familiarity, if not family. This paper reviews the social relations expressed through co-burials, and aims to better understand relationships between couples, siblings, or parents and children. The chapter particularly highlights mother-child relationships and presents graves of pregnant women and graves of women and children buried together, in order to understand how such individuals were treated by their societies in death. Ages and age gaps between co-buried individuals reveal the most likely ages for life-transitions such as first motherhood and the addition of new family members. The analysis compares evidence from two different, but contemporary cultural groups (Únětice and Unterwölbing) to shed light on prehistoric gender relations, family structures and social organisation through the lens of the burial record.

Keywords: Bronze Age, Austria, motherhood, age relations, mother, child

Address: Institute for Oriental and European Archaeology, Austrian Academy of Sciences, Hollandstraße 11+13, 1020 Vienna, Austria

Email: Katharina.Rebay-Salisbury@oeaw.ac.at

\section{Introduction: Social Relations and Motherhood}

In Early Bronze Age Austria, and the surrounding areas, people were usually buried individually in single graves. The exceptions in which two or more bodies came to rest in a single grave structure, however, are of interest as they may reveal evidence of social relations between the buried individuals. This chapter investigates potential social relations that may have existed between co-buried individuals with a particular emphasis on mother-child relationships. It surveys the kinds of people who were buried together in Bronze Age Lower Austria, and explores if mothers and children are more frequently buried together than other combinations. Co-buried mothers and children may give us insights into prehistoric motherhood.

It is surprising how little we effectively know about Bronze Age motherhood (but see Rebay-Salisbury 2017a), apart from the obvious conclusion that women had children and, together with other caregivers, managed to raise some of them sufficiently well so that their offspring went on to have children themselves. Through an investigation of the graves of pregnant woman and burials of women with young children, we may gain important insights concerning the social structure of past societies, for instance, the age at which women first became mothers, levels of maternal and childhood mortality, the average number of children a mother would have had, in addition to gaining details in relation to child spacing.

The pilot study 'The Social Status of Motherhood in Bronze Age Europe' ${ }^{1}$ focused specifically on the development of a methodology to address the physical anthropology of motherhood. To find mothers in the archaeological record, we recorded burials of pregnant women and women buried with small children, testing their relatedness via ancient DNA analysis whenever possible. The physical anthropologists in the team, Doris Pany-Kucera and Michaela Spannagl-Steiner, investigated physiological traces of pregnancy and birth-related stress on the female skeleton. The bones 
of the pelvis are joined by ligaments, which are under pressure during pregnancy and expand during childbirth. These physiological changes in the ligaments, triggered by hormones and basic physics, create stress marks on the skeleton such as the preauricular sulcus (Breitinger 1990; Ubelaker and De La Paz 2012; Maass and Friedling 2016). Whilst we do not assume that social mothering necessarily has to be undertaken by the biological mother, especially for older children, we assume that a close relationship would have existed between the biological mother and child for at least the period of breastfeeding.

The European Research Council Starting Grant project 'The Value of Mothers to Society: Responses to Motherhood and Child Rearing Practices in Prehistoric Europe'2 expanded upon the methodology to systematically investigate the link between women's social and reproductive status and to explore social responses to pregnancy, birth and early childrearing in prehistoric societies. Taking a long-term history approach, it has tracked social developments over three millennia from the Late Neolithic to the Late Iron Age in central Europe. By combining the latest developments in archaeological science with innovative interpretative approaches, it aims to understand if and how women's social status changed as they became mothers and how motherhood was conceptualised.

\section{Burial Practices in Bronze Age Lower Austria}

Early Bronze Age burial practices in eastern Austria (c. 2200-1600 BC) are dominated by the wide-spread deposition of bodies in a flexed position in cemeteries. Most graves include a limited set of personal dress elements and jewellery (various rings and pins being most common), while weapons and tools are rare. Ceramic vessels, such as bowls and cups, are placed in graves as containers for food and drink but their number rarely exceed two or three pieces (e.g. Neugebauer 1994; Lauermann 2003).

Lower Austria is the meeting point of three Early Bronze Age European cultural complexes - the Únětice complex, distributed from Thuringia and Saxony over Bohemia and Moravia to Silesia, Slovakia and Lower Austria; the southern German Bronze Age cultural groups extending westwards, and groups of the Carpathian Basin extending eastwards. The three contemporaneous groups differ most markedly in the way bodies were placed after death (Fig. 1) (Neugebauer 1994; Krenn-Leeb 2011, 11-12).
Lower Austria north of the Danube belongs to the Unnětice complex, where heavy cast bronze objects are preferred and the occurrence of royal graves (Kienlin 2008) is suggestive of a complex social order. Únětice funerary rites included the placement of bodies in a flexed position on their right side, with the head to the south and looking towards the east. Women and men were positioned in the same way and double and multiple burials are fairly common. The cemeteries are located near settlements and comprise a dozen to several dozen graves (Lauermann 1995; 2003; Rettenbacher 2004).

Lower Austria, south of the Danube and west of the Viennese woods, is home to the Unterwölbing group, characterised by elaborate and highly decorated bronze objects made of sheet bronze. This group is linked to a cluster of southern German Bronze Age cultural groups. Social differences are marked both by the depth of graves and the composition of grave inventories; grave robbing (Sprenger 1999) was common. In the Unterwölbing group, bodies were placed according to gender - men were positioned on the left side with the head to the north, while women lay on the right side with the head to the south - both looked towards the east. This strict assignment of gender was observed even for infants and small children, if they were present in the cemetery; demographic analysis suggests that many dead babies and small children must have been placed outside the communal cemetery. Cemeteries of several hundred to thousands of individuals are known (Neugebauer 1991; Neugebauer and Neugebauer 1997; Blesl 2006).

The Wieselburg group (Leeb 1987) is situated south of the Danube in the east of Austria and in Slovakia, between the Viennese woods and the River Raab; it is culturally linked to Bronze Age groups of the Carpathian Basin. Flexed inhumations in flat cemeteries or cemeteries with small burial mounds are common. Most individuals are buried with the head towards the south-west; over $70 \%$ of males are placed on the left side, while over $90 \%$ of females lie on the right side (Neugebauer 1994, 60). Pottery is an important component of grave inventories, while bronze items are not as prominent as for other groups. The cemeteries of Hainburg/Teichtal and Mannersdorf am Leithagebirge, with over 400 very well preserved individuals, are currently being studied and prepared for publication by Alexandra Krenn-Leeb (2011) and are therefore not included in this survey.

The total of over 3,100 individuals from Early Bronze Age Austrian graves provides an ideal data set for the 


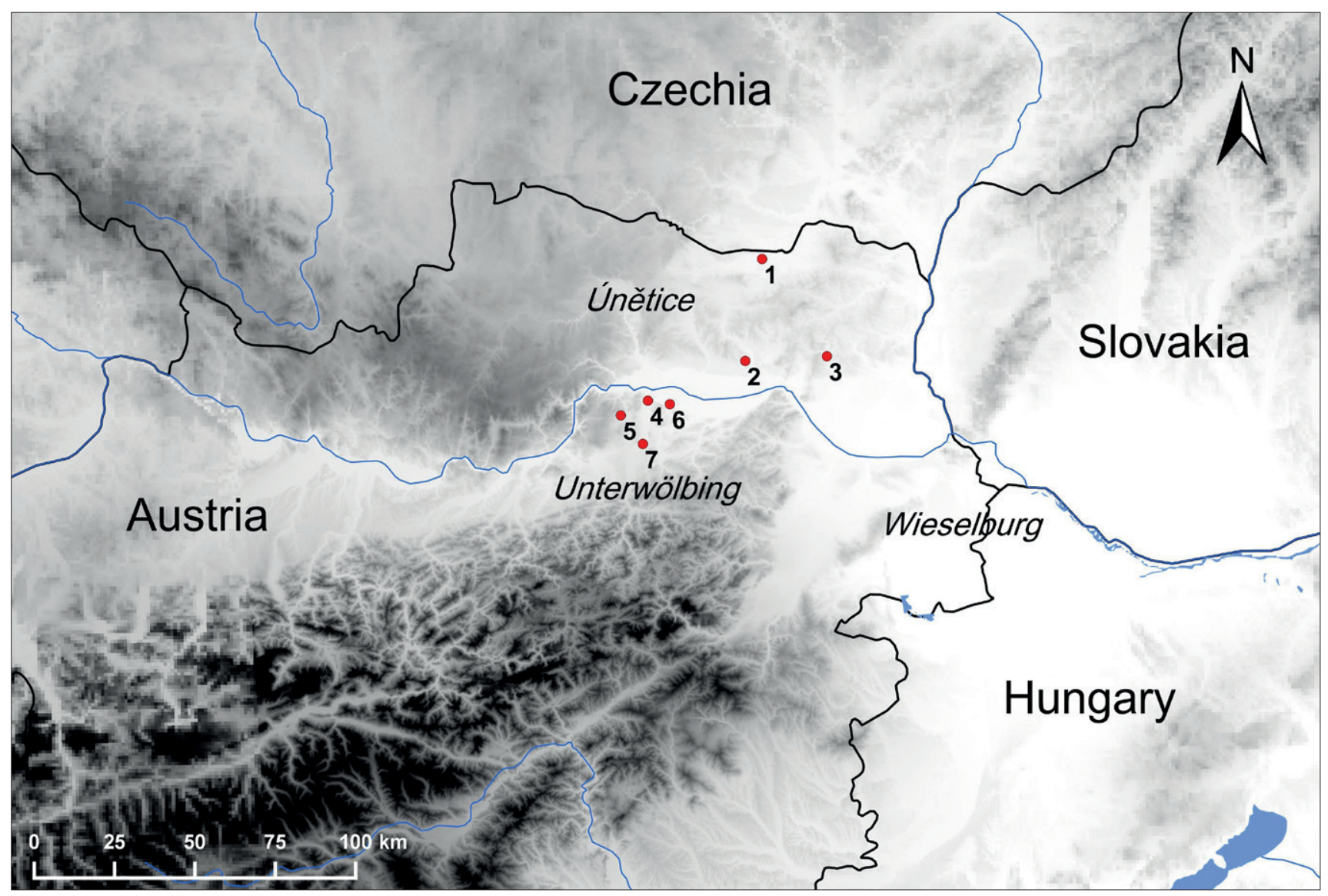

Figure 1: Sites mentioned in this chapter: 1. Zwingendorf, 2. Unterhautzenthal, 3. Schleinbach, 4. Franzhausen, 5. Unterwölbing, 6. Gemeinlebarn, 7. Pottenbrunn (๔ Roderick B. Salisbury).

study of the physical anthropology of these populations, including morphology, demographics, trauma and disease (Berner 1988; Wiltschke-Schrotta 1988; Teschler-Nicola 1994; Teschler-Nicola and Prossinger 1997; Novotny 2006; Spannagl-Steiner et al. 2011). In the following two sections, sites of the Unětice and Unterwölbing Bronze Age groups will be compared with respect to the social relationships expressed in double, multiple and consecutive graves.

\section{Double and Multiple versus Consecutive Burials}

In societies for which single burial was the norm, the placement of two or more dead bodies together in one grave is remarkable. In this approach it is important to clearly differentiate double and multiple burials, which are considered as bodies buried at the same time or within a very short period, from consecutive burials. The latter may include the re-use of graves, after a short or considerable period of time, and enable us to speak of first and second burials. The terms primary and secondary burials are avoided here, as secondary burial often implies that the body had already been buried elsewhere before it was deposited for a second time (e.g. Orschiedt 1997; Weiss-Krejci 2001; Duday 2009, 14; Knüsel 2014, 47); in the case studies discussed below, second burials involve the interment of bodies both before and after decomposition. Duday's term 'collective burial' does not quite apply here since, as per his definition, 'burials are collective where the corpses have been deposited at different times and where the structure has been built to allow for reopening for further depositions' (Duday 2009, 13). The first condition is met, but there is ambiguity about the second since, as we will see, it is not clear if the grave was intended to be re-opened in all cases of second burials.

In practice, double and multiple burials are not always easy to distinguish from consecutive burials, especially if the graves were excavated a long time ago and were poorly documented. Both forms of burial, however, may express relations between persons. In the latter case, the temporal delay between the depositions puts interpretations on a much less secure ground.

For double and multiple inhumation graves, it is most likely the individuals died together, or in brief succession, although the storage of bodies for a period after death is possible in the right environment, such as cold 
and freezing conditions, or through the use of artificial mummification techniques. The cause of death remains unknown for most Early Bronze Age individuals and there are only a few cases where circumstantial evidence is suggestive of death due to disease or violence. The community who buried the dead must have had reasons to bury people together that extends beyond the practical reason that the creation of a single grave for two people is less effort. The grave structures in which people were buried together do not suggest that saving labour was the primary motive for double and multiple burials. Rather, the preservation and articulation of social links between persons beyond death must have been paramount. In the small scale, tightly-knit communities of perhaps a hundred or fewer individuals that we envision for the Bronze Age, no members would have been strangers to one another. Nevertheless, the age and sex of co-buried individuals placed together points to a greater social meaning that is more than a random selection. Some combinations appear to reflect mother-child relations, nuclear families or sibling bonds. People close in life may have also had a greater risk of dying together if tragedy struck, for example, infectious disease or a raid. A common funeral would underline both their relationship during life and the common cause of death.

Consecutive graves, in which a second or more bodies are added to a first burial a considerable period of time after the initial funeral, are less likely to be linked by a common cause of death (Duday 2009, 98). The reasons for creating a link between the buried individuals through the funerary practice may be familiarity and close personal connections in life, but also family relations, descent and, further removed, the genealogical link to an ancestor. If no true genetic link existed, the spatial placement in proximity to the dead may underline claims to a social ancestor, an effort to be part of a social community and a continuation of memory of the deceased. In burial spaces of multi-period use it is also possible that graves were 'unintentionally' reused; the same plot was used again for a burial without a link to the previous owner.

\section{Social Relationships in the Unětice Group (Lower Austria North of the Danube)}

According to Únětice burial customs, bodies were placed in graves in a flexed position on the right side and orientated south to north. Most people were buried with a small amount of jewellery and personal items, a few pieces of pottery and animal bones. Most graves are single graves with wooden coffins, but some variability is evident and the deposition of two or multiple bodies at the same time in one grave is not uncommon. Zwingendorf, Grave 8, for example, contained two bodies but it could not be fully ascertained if both individuals were buried simultaneously or whether they ended up in this configuration as a result of a second burial. A female adolescent (15-16 years) was buried next to a four-year-old child. Both were flexed and lay on the right side of the body, with the head to the south-west; the girl lay behind the younger child (Grefen-Peters 1982; Wewerka 1982). Grave robbing was practiced in Unětice cemeteries, but not as regularly and intensively as for the area south of the Danube.

Most well-excavated archaeological sites suggest the close proximity, if not blending, of settlement and cemetery locations. Small cemeteries found near the settlements were used, but a considerable number of people were also buried in decommissioned settlement features, such as storage pits (Lauermann 1992). It remains unclear if they should be seen as 'deviant burials', however, or as integral parts of regular burial customs.

\section{Schleinbach}

Schleinbach is one such site that includes settlement features, two small cemeteries or grave groups and bodies, as well as body parts, deposited in pits. Located on the premises of a brick factory, the first finds came to light in 1911, but systematic excavations by Karl Krieger did not start until 1926. The remains of fortythree individuals were recovered (Weninger 1954a; 1954b; Rettenbacher 2004), but not all of them were anthropologically analysed and a re-assessment of the skeletal material is in progress (Pany-Kucera et al. in prep.). Table 1 lists the graves that contained the remains of more than one individual.

Whether Skeletons 15 and 18 are indeed components of a double burial is doubtful; both skeletons were placed on the right side, with the head to the southwest and the man lay in front of the woman. Enough space exists between the two individuals, however, to make it feasible that they were single burials. Grave pits or intercutting features were not observed at the time of excavation. Grave 30/31 is different and here two male individuals are buried shoulder on shoulder and leg on leg. The two men, one aged 27-31 years, and the other aged 30-35 years, seemed to have met the same fate - both displayed a depressed fracture on the 
Table 1: Burials with more than one body at Schleinbach, Lower Austria (after Weninger 1954a; 1954b; Rettenbacher 2004; Rebay-Salisbury et al. 2018).

\begin{tabular}{|l|l|l|l|}
\hline Grave & Individual I & Individual II & Description \\
\hline $15+18$ & male, 21-25 yrs & female?, 30-35 yrs & flexed, buried closely to each other \\
\hline $30 / 31$ & male, 27-30 yrs & male, 30-35 yrs & extended, buried closely together, skulls fractured perimortem \\
\hline 60 & male, 27-35 yrs & 3 children & aged 3-4 yrs, 8-9 yrs and 12-14 yrs \\
\hline 89 & male, 25-30 yrs & female, 30-35 yrs & second individual represented by cranium and cervical vertebrae \\
\hline 109 & male, 30-40 yrs & $2-3$ yrs & second individual represented by cranium only \\
\hline
\end{tabular}

considered significant enough for the remains to have been preserved in situ as a block in 1931 and since that time they have featured in various exhibits (RebaySalisbury 2018). Extra crania were found in Graves 89 and 109 buried as part of a secondary burial practice; Grave 89 was the burial of a man aged 25-30 years, to whom the cranium and cervical vertebrae of a woman aged 30-35 years had been added (no cut-marks were detected), while Grave 109 was the disturbed burial of a man aged 30-40 years which contained the cranium of a child of three years.

It appears that two phenomena are evident at Schleinbach: first, evidence of extraordinary and violent events, such as the double burial of two men who died violently and the deposition of a man with three children in a settlement pit in a manner that does not fit the model of a careful and loving deposition that one would expect a connected community to provide. The age gaps between the individuals in Pit 60 suggest the eradication of a whole family; perhaps a man with his offspring (ancient DNA testing for sex and relatedness is in progress). Second, there is evidence of second burial practices through the addition of extra crania in certain burials. In these cases, it is noteworthy that the first burials tend to be those of adult men, while the additions are derived from women and children (although at present, we cannot ascertain if they died after or before the first individual).

\section{Unterhautzenthal}

Unterhautzenthal, a settlement and cemetery site excavated during the 1980s and 1990s, included bodies from both pits and the cemetery (Table 2) (Lauermann 1991; 1995). A recent re-analysis of the human remains has revealed evidence for further individuals - primarily neonates and children - that were amongst the recovered material, but not individually recorded during the excavation (Rebay-Salisbury et al. 2018). Inclusion of these skeletons has raised the total number of individuals excavated at Unterhautzenthal to fifty-eight, with thirty-two (55\%) comprising sub-adults less than twenty years of age. 


\begin{tabular}{|c|l|l|l|}
\hline Grave & Individual I & Individual II & Description \\
\hline 27 & $6-7 \mathrm{yrs}$ & $2-3 \mathrm{yrs}$ & buried in embrace \\
\hline 38 & female, $14-15 \mathrm{yrs}$ & neonate & added during re-analysis \\
\hline 93 & female, 20-25 yrs & female, 35-45 yrs & consecutive burials, older woman added later \\
\hline 95 & female, 35-45 yrs & 5 yrs, 3-4 yrs & \\
\hline 103 & female, 16-20 yrs & 3 yrs & added during re-analysis \\
\hline 109 & female, 50-60 yrs & neonate & added during re-analysis \\
\hline 116 & female, 45-60 & $4-6$ yrs & added during re-analysis \\
\hline 122 & male, 35-40 yrs & female, 17-20 yrs neonate & \\
\hline
\end{tabular}

Table 2: Burials with more than one body at Unterhautzenthal, Lower Austria (after Lauermann 1991; 1995; RebaySalisbury et al. 2018).

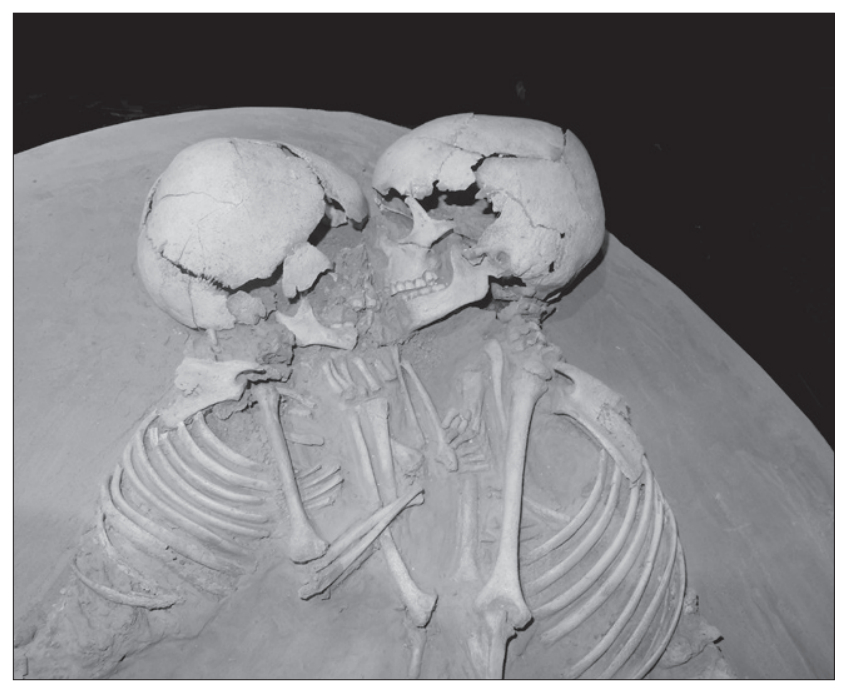

Figure 3: The children from Unterhautzenthal, as displayed at the MAMUZ museum in Asparn, Lower Austria (๑ Katharina Rebay-Salisbury).

At Unterhautzenthal, emotive relationships between persons were expressed in the manner that the bodies were placed in their graves. Perhaps most striking is the double burial of two children, aged two and six years, in an embrace in Feature 27, a probable former storage pit. Buried flexed on the right side, with the head to the south-west, the older child follows the regular burial rite more closely, whereas the younger one was placed in a manner that respected the position of the older child's body, and may reveal a ranking based on age (Fig. 3). The age gap of around four years would be typical for siblings in an agrarian community that breastfed their infants (e.g. see Fulminante 2015).

Grave V93 can be interpreted as a consecutive grave; the articulated and only minimally disturbed body of a woman aged 35-45 years was found about 35 $\mathrm{cm}$ higher than the completely disturbed remains of a younger woman of 20-25 years. Grave V95 was the grave of a woman, aged 35-45 years, with two children. The younger (3-4 years) was placed in front of her face, while the older (5 years) was positioned in a space behind her legs. The grave was deep and well equipped the older child was buried with an arm ring and a bone ring often associated with daggers; perhaps it was a little boy. Grave V122 can be interpreted as a family grave of a man, woman and baby. The man was aged 35-40 years old when he died, or perhaps slightly older since tooth cementum annulation analysis produced an age-at-death of $47+/-5$ years. ${ }^{3}$ The woman was considerably younger and aged between 17 and 20 years. The grave had been disturbed prior to the excavation and the bones of the neonate were not recognised at the time of excavation so unfortunately their original position within the grave is unknown.

Careful re-analysis of the Unterhautzenthal skeletal material (Rebay-Salisbury et al. 2018) revealed the remains of an additional four neonates or young children in addition to those already published. If we work with the hypothesis that the women buried with these remains were indeed their mothers, this points to a relatively young age of first motherhood, but also to the presence of some older mothers. All women buried with babies were placed in large grave structures with grave goods and were therefore considered to have high social index values, which is suggestive that motherhood was socially rewarded. At Unterhautzenthal, the relationship between mothers and children seems to be a dominant theme. It needs to be remembered, however, that, in comparison to Schleinbach, it was excavated more recently and recorded in greater detail.

We know little about the relationships between mothers and children in life. A study of the isotopic signatures in the bones and teeth from Unnětice material from Poland (Pokutta and Howcroft 2015) has provided insights in relation to feeding and weaning practices. It suggests that breastfed babies were supplemented with solid foods early, perhaps before six months, but the 


\begin{tabular}{|c|l|l|l|}
\hline Grave & Individual I & Individual II & Description \\
\hline 102 & male, $40-45 \mathrm{yrs}$ & female, $30-40 \mathrm{yrs}$ & consecutive burial, woman added later \\
\hline 392 & $17-20 \mathrm{yrs}$ & male, $20-25 \mathrm{yrs}$ & consecutive burial, mandible of male added later \\
\hline 636 & male, 11-12 yrs & female, 20-60 yrs & consecutive burial, woman added later \\
\hline 851 & female, $40-60 \mathrm{yrs}$ & male, 20-25 yrs & consecutive burial, male mandible added later \\
\hline
\end{tabular}

Table 3: Burials with more than one body at Pottenbrunn, Lower Austria (after Blesl 2006). time of cessation of breastfeeding could not be securely established. For agricultural communities, such as those of the Early Bronze Age Lower Austrian region, a weaning age of between two and four years is usually suggested (Rebay-Salisbury 2017b).

\section{Social Relationships in the Unterwölbing Group (Lower Austria North of the Danube)}

The Unterwölbing group continues in the lowland areas south of the River Danube. In the valley of the Traisen, a tributary of the Danube, over 3,100 graves have been unearthed, in part as a result of extensive rescue excavations undertaken in the 1980-90s (Neugebauer and Neugebauer 1997, 10). Noteworthy sites include the eponymous site of Unterwölbling (Ehgartner 1962; Kaiser 1962), Franzhausen I (Neugebauer and Neugebauer 1997), Franzhausen II (which still awaits full publication, Neugebauer 1999), Gemeinlebarn A (Bertemes 1989), Gemeinlebarn F (Neugebauer 1991) and Pottenbrunn (Blesl 2006).

The Unterwölbing group practiced a gendered body placement during the funerary ritual. Men were placed on the left side with the head to the north, while women were laid on their right side with the head to the south; both looking towards the east. This pattern seems to have been inherited from Bell Beaker traditions and was rigidly adhered to even for children. The placement of the body thus informs us that people differentiated strongly between male and female bodies from birth, which makes gender one of the most important categories according to which people were perceived in the Early Bronze Age (Sørensen 2013). If the morphological sex can be determined, it matches the gendered body position and orientation in almost all cases in this Bronze Age group. It is therefore possible to assign buried persons a gender, on the basis of the gender specific body position, much more reliably than via gender typical grave goods.

The skeletal preservation is not optimal due to the gravel bedrock, and many graves were found in disarray.
In addition, up to $80 \%$ of the graves per cemetery were found with objects removed and bones disordered; systematic grave robbing might have been carried out to gain material wealth (Neugebauer 1994, 140; Sprenger $1999,18-20)$, possibly by groups unconnected to the burial community. The upper body was specifically targeted and in many cases a temporal proximity of burial and re-opening could be established, as some skeletons appear to have still been articulated at the time of disturbance. These findings, in addition to the repetitive nature of the practice, have been interpreted as evidence that the re-opening may have been a ritual and socially sanctioned activity (Primas 1977, 107; Rittershofer 1987). In the Traisen valley, it appears that grave robbing involved the re-opening of several graves at the same time, during which bronze objects were removed and body parts of individuals were rearranged, removed and/or added to other graves (Neugebauer 1991). For the first interments, individual burial is the norm; in most cases, only one body was carefully placed per grave.

\section{Pottenbrunn}

At Pottenbrunn (Blesl 2006), for example, no direct evidence for double burials or second burials was recorded (Table 3). Of seventy-four north-south orientated grave pits, sixty-nine included human remains, four of more than one individual, which is explained by the wide-spread practice of re-opening (Blesl 2006, 18).

Grave 102 was a completely disturbed grave of a 40-45-year-old man. The skeletal remains of a second individual (102/2: female 30-40 years) perhaps entered the grave as a result of grave robbing. Alternatively, it may confirm a relationship between the couple after death, a man and woman with an age difference of approximately ten years. Grave 392 was originally interpreted as representing a double burial, the addition of a second individual to the grave or the deposition of the skeletal parts of a second individual as a consequence of grave robbing. Individual 392/1 consisted only of a mandible, which was identified as that of an adult male, c. 20-25 years old. Individual 392/2 comprised post-cranial skeletal elements of an individual 
aged 17-20 years, with incomplete epiphyseal fusion. The skeleton was gracile and only two features for sex estimation were evident, both of which are suggestive of a female individual, but one with strong muscle markings. ${ }^{4}$ Grave 636 included Individual 636/1, the body of a tightly flexed boy (11-12 years), lying on the left side with the head orientated to the north. Further post-cranial remains belonged to Individual 636/2, those of an adult woman (20-60 years), which might have been added during post-funerary activities. This could indicate a mother-child or grandmother-grandchild relationship. Grave 851 still contained the lower body of Individual 851/2, a 40-50-year-old woman with a bronze pin in the chest area, in situ. A mandible of a male aged 20-25 years (Individual 851/1) was also found in the same grave. The age difference is a strong argument for the presence of two individuals. If this addition is at all meaningful, it could indicate the relationship of an older woman with a young man, or alternatively, a mother-child or mother-grandchild relationship between the woman and the younger man.

\section{Unterwölbing}

Nothing is known about the way bodies were placed or orientated at Unterwölbing; Josef Bayer, who excavated the majority of the graves between 1904 and 1928, died before he could publish any details. The cemetery report lists five of fifty-two graves as having comprised double graves (Table 4) (Ehgartner 1962; Kaiser 1962). It is unclear if they can be regarded as multiple or consecutive burials, however, and no specific patterns emerge from the age and gender combinations.

Table 4: Burials with more than one body at Unterwölbing, Lower Austria (after Ehgartner 1962; Kaiser 1962).

\begin{tabular}{|c|l|l|}
\hline Grave & Individual I & Individual II \\
\hline 5 & male, 20-40 yrs & male, 18-20 yrs \\
\hline 14 & male, $60 \mathrm{yrs}$ & $3-6 \mathrm{yrs}$; 1 -2 yrs \\
\hline 18 & male, $25-30 \mathrm{yrs}$ & female, 20-30 yrs \\
\hline 26 & $14 \mathrm{yrs}$ & $5 \mathrm{yrs}$ \\
\hline 27 & male, 30-35 yrs & $?$ \\
\hline
\end{tabular}

\section{Franzhausen I}

With 716 excavated grave pits, the data from the cemetery of Franzhausen I, excavated between 1981 and 1983 (Neugebauer 1999), is more varied (Table 5). Again, single interment is the norm, but eighteen graves contained the remains of more than one individual; this includes three graves of pregnant woman, five graves with double and multiple burials and ten graves with first and second burials.

Despite the poor skeletal preservation, three graves of pregnant women were documented at Franzhausen I. The ages of the mothers range from early adult to mature. The youngest of the women was 20-25 years old and buried in Grave 309. She was placed southnorth on her back with legs angled to the right side. The remains of a full-term foetus were found directly to the north of her pelvis, between and under the lower extremities of the women. This position suggests a post-mortem coffin birth, although a deliberate placement of a new-born under the newly delivered mother cannot be excluded (see Sayer and Dickinson 2013). The mother was deposited in a rather small grave pit. Grave goods include a bronze awl, flint tools, bone rings, molluscs and a set of pottery. The 30-40 year-old-mother from Grave 941 was placed in a similar way, with the full-term foetus head down still within the pelvic area. The woman's grave had been reopened after burial and objects were removed from her head and chest area. Upon excavation, her grave still included a bronze awl, a shell necklace, a dress pin with disc head, pottery and animal bones. Instead of the usual single bowl, two had been placed in the grave - one perhaps intended for the unborn child (Neugebauer and Neugebauer 1997, 26). Grave 139, the grave of a woman aged 40-60 years was found disturbed with the exception of the lower legs. The remains of a seven-month-old foetus to neonate were preserved by copper salts from bronze grave goods in the pelvic region of the buried woman. The manner in which these women were buried suggests that mothers who died in late pregnancy, during childbirth or shortly after birthing were not treated differently to other women at Franzhausen I; grave goods possibly linked to childbirth included cutting devices and objects that may be interpreted as amulets or charms, such as beads. Another grave of a pregnant woman was found at the nearby cemetery of Franzhausen II. The grave dates late in the Early Bronze Age, around $1600 \mathrm{BC}$, and is one of the first in the community in which the bodies were burnt rather than inhumed. The cremation grave included the remains of a woman aged 24-40 years with an almost full-term foetus/neonate in a large ceramic vessel, deposited in a small pit with two bronze arm rings (Reiter 2008, 279).

At Franzhausen I, only four burials qualify as double or multiple interments, as the individuals were deposited together or very close in time. Grave 288 is that of two children, most likely young girls; both were placed in the same position, like a woman lying on the right 
Table 5: Burials with more than one body at Franzhausen I, Lower Austria (after Neugebauer and Neugebauer 1997).

\begin{tabular}{|c|c|c|c|}
\hline Grave & Individual 1 & Individual $2(+3)$ & Description \\
\hline 84 & female, $20-30$ yrs & female, $30-40$ yrs & consecutive grave, older woman added later \\
\hline 139 & female, $40-60$ yrs & foetus & pregnant woman \\
\hline 259 & male, $30-40$ yrs & female, $18-22$ yrs & consecutive grave, woman added later \\
\hline 288 & female, $11-14$ yrs & female, $4-5 \mathrm{yrs}$ & double burial, older child placed behind younger child \\
\hline 309 & female, $20-25$ & foetus & pregnant/newly delivered woman \\
\hline 329 & $7-8$ yrs & $7-9 \mathrm{yrs}$ & consecutive grave, older child added later \\
\hline 339 & female, $18-22$ yrs & $6-8 \mathrm{yrs}$ & consecutive grave, child added later \\
\hline 400 & female, $30-50$ yrs & female, $30-50 \mathrm{yrs}$ & consecutive grave \\
\hline 445 & $14-80 \mathrm{yrs}$ & $1-2 \mathrm{yrs}$ & consecutive grave, child added later \\
\hline 588 & male, $35-50$ yrs & male, $10-12$ yrs & double burial, child placed behind man \\
\hline 599 & male, $20-25$ yrs & female, $14-16$ yrs; female, $12-14$ yrs & triple burial, man placed first, then older girl, then younger girl behind older girl \\
\hline 662 & male, $50-70$ yrs & female, $25-35$ yrs & single burials, double grave \\
\hline 728 & male, $25-35$ yrs & $6-7 \mathrm{yrs}$ & consecutive grave, child added later \\
\hline 777 & female, $25-30$ yrs & female, $50-70$ yrs & consecutive grave, older woman added later \\
\hline 840 & male, $20-25 \mathrm{yrs}$ & female, $40-60$ yrs & consecutive grave, older woman added later \\
\hline 860 & $3-5$ yrs & female, $35-50+y r s ; 7-8$ yrs & $\begin{array}{l}\text { consecutive grave, } 3-5 \text { year old buried first, woman and 7-8 year old buried } \\
\text { together later }\end{array}$ \\
\hline 924 & male, $20-30$ yrs & male, $18-25$ yrs & double burial, older man placed behind younger man \\
\hline 941 & female, $30-40$ yrs & foetus & pregnant woman \\
\hline
\end{tabular}

side of the body, and the younger, aged 4-5 years, was placed in front of the older child (11-14 years). Grave 588 contained a man of 35-50 years lying on the left side, as was customary for males; a child of 10-12 years was placed behind the man's back in a similar position. In Grave 924, two males of 18-25 years and 20-30 years, were found again in a similar position, with the older of the two individuals placed behind the younger. Most interesting is perhaps the triple burial in a narrow wooden coffin discovered in Grave 599. It held the remains of a man of 20-25 years, ${ }^{5}$ placed on the left side with the head to the north, the usual placement for men. Two young individuals, the older one aged 14-16 years and the younger one aged 12-14 years, were found at his feet. Both lay on the right side of the body with the head to the south, as was customary for women; morphological traits support the classification as females. Overlapping of the skeletal elements made it clear that the man had been placed in the coffin first, followed by the older of the females, with the younger one placed behind the older one's back; all in a single act of deposition. The grave had been re-opened since the upper body of the man was disturbed and the cranium was removed, but not the mandible. Although the remains of the younger female appeared to be in situ, green stains on the distal ends of both the right radius and ulna (contra Sprenger 1999, 127) indicate she might have worn a bracelet on her arm when she was buried that had subsequently been removed.

In these four burials, individuals buried body-onbody and placed and orientated the same way were of the same gender and, where it was possible to determine, of the same sex. There seems no clear pattern as to which age was placed first: on two occasions the older individual was placed behind the younger one and on two instances the opposite was true. The triple burial of individuals relatively close in age may be suggestive of a sibling relationship, although a marital relationship of a man with two young wives is equally possible (Fig. 4). At present, an analysis of morpho-genetic traits as well as an attempt at establishing genetic relatedness via ancient DNA analysis is in progress.

Grave V622 is slightly different from the burials discussed above, as in this case, two separate wooden coffins were placed parallel in one grave pit. Both persons were placed on their left sides with head north, as men 


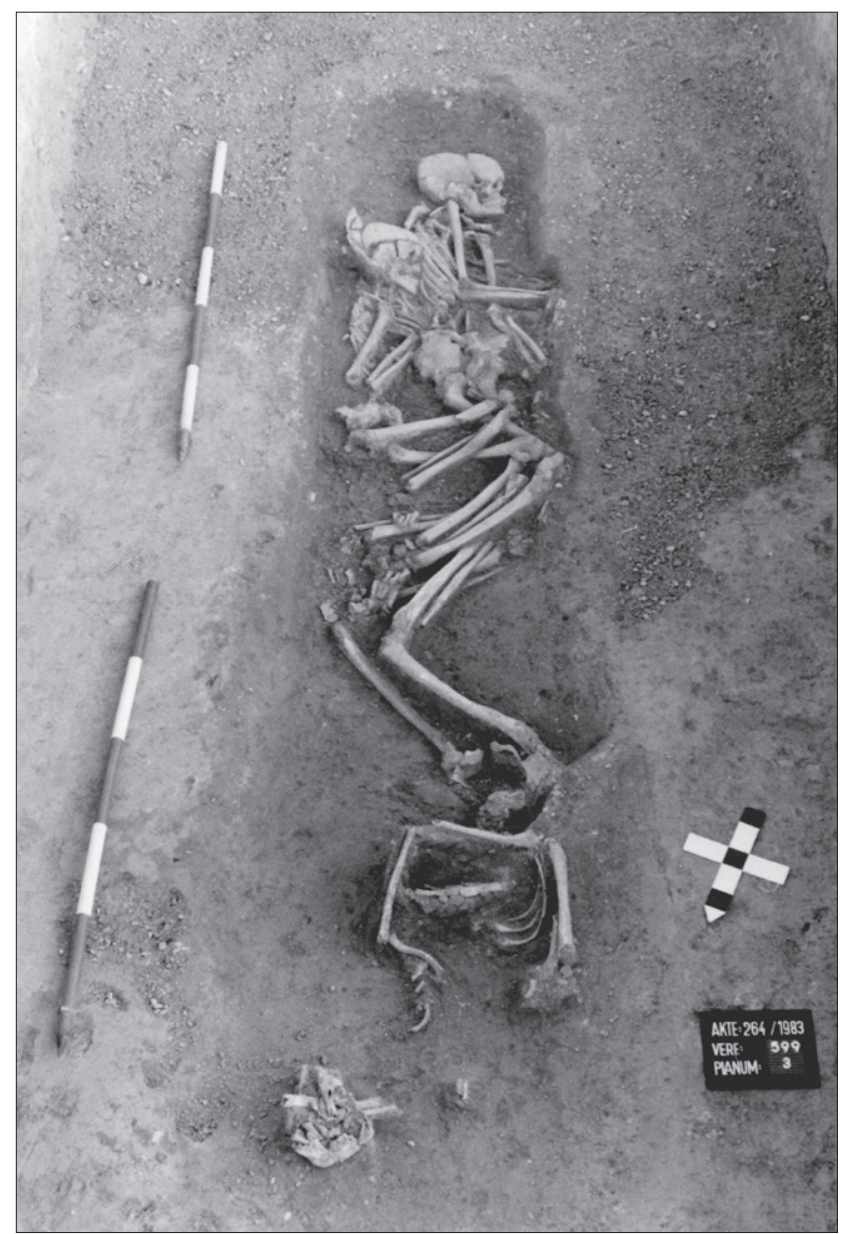

Figure 4: Grave 599 from Franzhausen I, Lower Austria () Bundesdenkmalamt Wien/Niederösterreich).

usually are. Only the left individual, a 50-70-year-old buried with an axe, a neck ring, a dress pin and some food provisioning was sexed as a male; the right individual placed in front of the old man was a 25-35-yearold woman with a dress pin, a bowl and animal bones. The shared grave pit suggests that the individuals had some sort of relationship, perhaps as siblings, marriage partners, or as master and servant. That the woman was buried following male funerary placement is very unusual and requires an explanation; her mimicking his body position perhaps suggests a subordinate role for the woman, who was considerably younger than the man.

Ten instances of consecutive graves were documented at Franzhausen I. These are graves for which a first burial could be clearly distinguished from a second burial in the same excavated feature, and which represented separate episodes of deposition. At Franzhausen I, it is most likely that bodies were indeed added to a pre-existing grave (in the sense of a collective burial), as grave pits usually do not overlap or intercut; the second burial takes place within the confines of the grave pit of the first burial and a substantial layer of soil is evident between the two individuals. No evidence for the stacking of coffins on top of each other came to light (such as in Gurgy, France, $c f$. Rottier et al. 2005). The fact that the bodies are stacked on top of each other, as in the manner of a bunk bed, gave rise to the German name 'Etagengräber'. There is a remote possibility, however, that the first burial had been decommissioned and forgotten by the time the second body was placed in exactly the same space. In some cases, the lower body remained in situ, whilst the upper one was disturbed; but it was more usual for both burials to have been found disturbed.

That two bodies were buried in the same grave does not necessarily imply a social relationship between the interred individuals. The age and gender data contained within Table 5, however, suggests the selection of people buried as second individuals was not entirely random. The combination of two women occurs three times (Graves 84, 400 and 777), while the combination of men and women occurs in Graves 259 and 840 and, in both cases, the man is buried first. Combinations of children (Graves 329), or women and children (Graves $339,728,860)$ are more frequent. No men are amongst the second burials. ${ }^{6}$

\section{Gemeinlebarn Cemeteries}

The Gemeinlebarn cemeteries are located approximately $8 \mathrm{~km}$ to the east of Franzhausen and are of comparable size and structure; the chronological focus is slightly later but still within the Early Bronze Age (Table 6). The majority of the cemetery Gemeinlebarn F was excavated between 1978 and 1981. Amongst the 258 graves, no double or multiple interments were documented, but two graves were found as second burials in the already disturbed context of a first burial. Grave 27 contained the remains of a woman of 30-35 years and, at a later stage, a child of 4-5 years was added to the fill. Grave 100 held the body of two males; the initial burial was that of an individual of 30-40 years, while the second burial comprised an individual of 27-33 years. According to Johannes-Wolfgang Neugebauer (1991, 77, 141), these later depositions occurred during grave robbing activities.

At Gemeinlebarn A, the situation is more complicated since this part of the extended Bronze Age necropolis was excavated in the early part of the twentieth century and recording of the grave contexts lacked detail (Szombathy 1929; 1931). In many cases it was not possible to distinguish double and multiple from consecutive graves. Modern excavations at Franzhausen I and 
Table 6: Burials with more than one body at Gemeinlebarn A, Lower Austria (after Szombathy 1929; Bertemes 1989) and Gemeinlebarn F (after Neugebauer 1991).

\begin{tabular}{|c|c|c|c|}
\hline Grave & Individual I & Individual II & Description \\
\hline F27 & female, $30-35$ yrs & $4-5$ yrs & consecutive burial, child added later \\
\hline $\mathrm{F} 100$ & male, $30-40$ yrs & male, $27-33$ yrs & consecutive burial \\
\hline A44 & female, $40-60 \mathrm{yrs}$ & female, $40-60$ yrs & consecutive burial, first intact, second disturbed \\
\hline A53 & male, $40-60$ yrs & young child & double burial or consecutive grave, adult c. $20 \mathrm{~cm}$ deeper, child in male position \\
\hline A60 & $\begin{array}{l}20-60 \text { yrs (female gender after } \\
\text { Bertemes 1989) }\end{array}$ & child & consecutive burial, adult disturbed, deeper than child \\
\hline A70 & $\begin{array}{l}14-20 \text { yrs (male position, female } \\
\text { gender after Bertemes 1989) }\end{array}$ & $0-2 \mathrm{yrs}$ & consecutive burial, infant added later? \\
\hline A80 & $14-40 \mathrm{yrs}$ & female, $20-40$ yrs & consecutive burial, remains of first burial moved aside \\
\hline A108 & $6-10$ yrs (male position) & female, $14-40$ yrs & consecutive burial, woman and extra cranium (14-20 yrs, female) added later \\
\hline A144 & 7-14 yrs, female? (male position) & female, $20-40$ yrs & consecutive burial, woman added later \\
\hline A166 & female, $20-40 \mathrm{yrs}$ & male, $20-40 \mathrm{yrs}$ & consecutive burial, disturbed remains of second burial \\
\hline A192 & male, 40-60 yrs & male, $20-60$ yrs & consecutive burial, disturbed remains of second burial \\
\hline A207 & $7-14 \mathrm{yrs}$ & $0-6$ yrs & grave of two children, disturbed; skull of older child found c. $10 \mathrm{~cm}$ deeper \\
\hline A215 & female, $20-40 \mathrm{yrs}$ & & $\begin{array}{l}\text { skulls and post-cranial elements of at least six persons (female adult, male adult, } \\
\text { two females } 14-20 \text {-year-old) in fill }\end{array}$ \\
\hline A225 & male, $20-40$ yrs & $0-12 \mathrm{yrs}$ & consecutive burial, remains of first burial moved aside, child added later \\
\hline
\end{tabular}

Gemeinlebarn F normally assigned human bones in the grave fill to second burials or grave robbing episodes; in many cases, the second burial was found disturbed, whilst the first was not, while in other cases both were found disturbed. Szombathy $(1929 ; 1931)$ interpreted such situations in a different way, however, and his a-priory assumption was that disarticulated bones stemmed from earlier burials that had been moved aside to make room for the second body. This corresponds to Duday's $(2009,72)$ notion of 'reduction'. Sex and age assignments are also problematic for Gemeinlebarn A. The skulls were collected and became part of the collection of the Anthropology Department of the Natural History Museum in Vienna but post-cranial elements were rarely kept. Sex determination of individuals on the basis of skulls alone, however, sometimes does not fit with other archaeological observations such as body placement and object combinations (an approach followed by Bertemes 1989). The table below thus includes Szombathy's (1929; 1931) sex determinations, but also Bertemes' (1989) assements of gender derived on the basis of body position and/or associated object combinations.

Gemeinlebarn A included thirteen second burials in previously used grave pits (nine according to Bertemes 1989, 27-8, 177), two of which may also be interpreted as double graves. Two second burials, Graves 80 and 225 , reached the depth of the first burial and moved the skeletonised bones to the side to make room for the new body. The others were placed in graves of lesser depth than the first burial. Particularly interesting is Grave 215, the burial of a woman of 20-40 years, who was buried with an elaborate set of jewellery made of molluscs, bone pendants, and bronze components. Bronze rings for the hair, fingers and arms completed the set (Bertemes 1989, 97-99). The grave fill included the skulls and post-cranial elements of at least six individuals, including the skulls of an adult man and woman as well as those of two 14-16-year-old females.

If we look at age and gender combinations in the first and second burials at Gemeinlebarn A and F, clear patterns are difficult to discern. The male body position is most common for first burials. Considering body position and orientation as the first indicator of gender, it appears that seven of the initial burials are those of men (and boys), and only four of women. Amongst the second burials, children are most frequently represented $(n=6)$, followed by women $(n=4)$ and men $(n=2)$. Young children are placed in the graves of men or other children as frequently as they occur in women's graves. As such, there seems to be no emphasis on the motherchild relationship. Two (male) children comprise first 
burials followed by women of childbearing age that theoretically could be their mothers. Overall, Gemeinlebarn does not seem to stress personal relations between the first and second buried individuals, but there is a tendency for men to be buried as the first interment within a grave.

\section{Comparison and Conclusions}

Comparing Early Bronze Age communities north and south of the Danube makes it clear that Unětice groups are more likely to bury people together and stage their connectedness through the arrangement of specific body positions. Most likely, the people buried together also died together. Double and multiple graves are most easy to interpret as family graves, including those of non-genetic communities such as sororities or 'brothers-in-arms'. Relationships between women and children seem particularly emphasised, a finding which suggests that motherhood was recognised as an important social foundation of Unětice societies. Women may have become first-time mothers when they were young teenagers. It is further interesting to note that when potential couple relationships are concerned, the combination of a man with a woman who is a decade or more his junior seems common.

South of the Danube, in contrast, individuals are almost always afforded individual graves, with only a few exceptions, such as the triple Grave 599 at Franzhausen I. Most cases of two or more individuals in one grave involve a first and second burial, where the second body is placed in the grave a considerable period of time after the first interment. If, in these cases, the motive is at all connected to personal relationships, no specific patterns can be discerned. It seems evident that first burials are more often made for men, whilst many of the later additions are children. Women with children, a connection that could be read as a mother-child relationship, are no more common than other combinations. The graves of pregnant women, albeit rare probably due to factors that include excavations techniques and skeletal preservation, likewise do not point to any special treatment of mothers.

The funerary rites of the Lower Austrian Unětice group may therefore be interpreted as having a more personal quality, that emphasises family relationships and emotive connections. South of the Danube, in contrast, it is the categorisation as man or woman that is central to the funerary rite, with personal relations fading into the background. Whether these different approaches to the burial of the bodies of loved ones reflect how individuals within these communities treated each other and interacted with one and other is open to debate and will require further investigations. Data on the frequency of head injuries at Unterhautzenthal and Pottenbrunn, for example (Spannagl-Steiner et al. 2016), found similar rates of interpersonal violence north and south of the Danube. The analysis of co-buried individuals in the central European Early Bronze Age and beyond during the course of the project 'The Value of Mothers to Society' will contribute new data to the discussions of relationships between the old and the young and, specifically, between mothers and their children.

\section{Acknowledgements}

I would like to thank the organisers of the EAA session in Vilnius 2016, Eileen Murphy and Grete Lillehammer, for the invitation to submit this paper, and Jo Appleby and the anonymous reviewers for reading and commenting on the draft. This research has received funding from the Austrian Science Fund FWF (P 26820) and the European Research Council (ERC) under the European Union's Horizon 2020 research and innovation programme (No. 676828). I would like to acknowledge Roderick B. Salisbury for producing the map and Michaela Fritzl, Doris Pany-Kucera, Roderick Salisbury and Michaela SpannaglSteiner for all the discussions about the material presented in this paper.

\section{Notes}

${ }^{1}$ Der Soziale Status von Mutterschaft im bronzezeitlichen Europa, FWF-funded project P 26820, 2015-2017. < https:// www.orea.oeaw.ac.at/forschung/prehistoric-identities/ der-soziale-status-von-mutterschaft-im-bronzezeitlicheneuropa>.

${ }^{2}$ The Value of Mothers to Society: Responses to Motherhood and Child Rearing Practices in Prehistoric Europe. ERC project VAMOS (grant agreement No 676828), 2016-2021, <https://www.orea.oeaw.ac.at/forschung/prehistoricidentities/the-value-of-mothers-to-society $>$.

${ }^{3}$ Carried out by Fabian Kanz at the Department of Legal Medicine at the Medical University of Vienna.

${ }^{4} \mathrm{~A}$ re-analysis of the skeletal remains of Pottenbrunn is in progress.

5. This individual was included in a TCA pilot study carried out at the Medical University in Vienna in collaboration with Fabian Kanz. The tooth cementum analysis returned an age of over forty years for this individual, which is inconsistent with the skeletal morphology. The age of this individual, published as 18-20 years (Neugebauer and Neugebauer 1997, 391) has since been corrected to 20-25 years by Doris Pany-Kucera and Michaela Spannagl-Steiner. Further analyses, including ancient DNA, are pending.

${ }^{6}$ Contrary to the initial sex determination (Neugebauer and Neugebauer 1997, 458), Michaela Spannagl-Steiner was able to unambiguously identify the sex of Individual 2, FN 9, as female on the basis of the pelvic morphology (Pany-Kucera et al. in prep.). 


\section{References}

Berner, M. 1988. Das frühbronzezeitliche Gräberfeld von Franzhausen I: Demographische und Metrische Analyse. Unpublished PhD thesis, Universität Wien.

Bertemes, F. 1989. Das frühbronzezeitliche Gräberfeld von Gemeinlebarn. Kulturhistorische und paläometallurgische Studien (Saarbrücker Beiträge zur Altertumskunde 45). Bonn: Habelt.

Blesl, C. 2006. Das frühbronzezeitliche Gräberfeld von Pottenbrunn (Fundberichte aus Österreich, Materialheft A 15). Wien: Berger.

Breitinger, E. 1990. Sulcus praeauricularis und Sulcus praesymphysialis als Fertilitätszeichen. Annalen des Naturhistorischen Museums in Wien 91, 63-78.

Duday, H. 2009. The Archaeology of the Dead: Lectures in Archaeothanatology. Oxford: Oxbow Books.

Ehgartner, W. 1962. Frühbronzezeitliche Skelette aus Unterwölbling, p. B. St. Pölten, NÖ. Archaeologia Austriaca 32, 62-84.

Fulminante, F. 2015. Infant feeding practices in Europe and the Mediterranean from prehistory to the Middle Ages: a comparison between the historical sources and bioarchaeology. Childhood in the Past 8, 24-47.

Grefen-Peters, S. 1982. Die frühbronzezeitlichen Skelette aus Zwingendorf. Anthropologischer Bericht. Archaeologia Austriaca 66, 49-60.

Kaiser, G. 1962. Das frühbronzezeitliche Graberfeld von Unterwölbling. p. B. St. Pölten, N.Ö. Archaeologia Austriaca 32, 35-61.

Kienlin, T. L. 2008. Der 'Fürst' von Leubingen: Herausragende Bestattungen der Frühbronzezeit als Bezugspunkt gesellschaftlicher Kohärenz und kultureller Identität, pp. 181-206 in Kümmel, C., Schweizer, B. and Veit, U. (eds.), Körperinszenierung - Objektsammlung - Monumentalisierung: Totenritual und Grabkult in frühen Gesellschaften (Tübinger Archäologische Taschenbücher 6). Münster: Waxmann.

Knüsel, C. J. 2014. Crouching in Fear: terms of engagement for funerary remains. Journal of Social Archaeology 14, 26-58.

Krenn-Leeb, A. 2011. Zwischen Buckliger Welt und Kleinen Karpaten. Die Lebenswelt der Wieselburg-Kultur. Archäologie Österreichs 22, 11-26.

Lauermann, E. 1991. Frühbronzezeitliche Bestattungen im Bereich einer bronzezeitlichen Siedlung in Unterhautzenthal, Gem. Sierndorf, Niederösterreich. Archaeologia Austriaca 75, 63-78.

Lauermann, E. 1992. Sonderbestattungen der frühen Bronzezeit. Praehistorische Zeitschrift 67, 183-200.

Lauermann, E. 1995. Ein frühbronzezeitliches Gräberfeld aus Unterhautzenthal, NÖ. Stockerau: Amt der Niederösterreichischen Landesregierung.

Lauermann, E. 2003. Studien zur Aunjetitz-Kultur im nördlichen Niederösterreich (Universitätsforschungen zur Prähistorischen Archäologie 99). Bonn: Habelt.

Leeb, A. 1987. Überblick über die Chorologie, Typologie und Chronologie der Wieselburgkultur. 100 Jahre Forschungsstand. Wissenschaftliche Arbeiten aus dem Burgenland 75, 231-83.

Maass, P., and Friedling, L. J. 2016. Scars of parturition? Influences beyond parity. International Journal of Osteoarchaeology 26, 121-31.

Neugebauer, C. and Neugebauer, J.-W. 1997. Franzhausen: Das frühbronzezeitliche Gräberfeld I. Horn: Ferdinand Berger \& Söhne.
Neugebauer, J.-W. 1991. Die Nekropole F von Gemeinlebarn, Niederösterreich. Untersuchungen zu den Bestattungssitten und zum Grabraub in der ausgehenden Frühbronzezeit in Niederösterreich südlich der Donau zwischen Enns und Wienerwald (Römisch-Germanische Forschungen 49). Mainz: Philipp von Zabern.

Neugebauer, J.-W. 1994. Bronzezeit in Ostösterreich (Wissenschaftliche Schriftenreihe Niederösterreich 98101). Wien-St. Pölten: Niederösterreichisches Pressehaus.

Neugebauer, J.-W. 1999. Rettungsgrabungen im Unteren Traisental in den Jahren 1998 und 1999. 15. Vorbericht über die Aktivitäten der Abteilung für Bodendenkmale des Bundesdenkmalamtes im Raum St. Pölten - Traismauer. Fundberichte aus Österreich 38, 483-575.

Novotny, F. 2006. Die krankhaften und traumatischen Veränderungen an den frühbronzezeitlichen Skelettresten des Gräberfeldes Pottenbrunn, pp. 147-202 in Blesl, C. (ed.), Das frühbronzezeitliche Gräberfeld von Pottenbrunn, Fundberichte aus Österreich, Materialheft A 15. Wien: Berger.

Orschiedt, J. 1997. Beispiele für Sekundärbestattungen vom Jungpaläolithikum bis zum Neolithikum. EthnographischArchäologische Zeitschrift 38, 325-45.

Pany-Kucera, D., Spannagl-Steiner, M. and Rebay-Salisbury, K. in prep. Early Bronze Age individuals from Schleinbach: a re-examination and complementary assessment of the skeletal material.

Pokutta, D. A. and Howcroft, R. 2015. Children, childhood, and food: the diets of subadults in the Únětice Culture of southwestern Poland, pp. 245-51 in Suchowska-Ducke, P., Reiter, S. S. and Vandkilde, H. (eds.), Forging Identities. The Mobility of Culture in Bronze Age Europe (BAR International Series S2771). Oxford: Archaeopress.

Primas, M. 1977. Untersuchungen zu den Bestattungstypen der ausgehenden Kupfer- und frühen Bronzezeit. Bericht der Römisch-Germanischen Kommission 58, 1-161.

Rebay-Salisbury, K. 2017a. Bronze Age beginnings: the conceptualisation of motherhood in prehistoric Europe, pp. 169-96 in Cooper, D. and Phelan, C. (eds.) Motherhood in Antiquity. New York: Palgrave Macmillan.

Rebay-Salisbury, K. 2017b. Breast is best - and are there alternatives? Feeding babies and young children in prehistoric Europe. Mitteilungen der Anthropologischen Gesellschaft in Wien 147, 13-29.

Rebay-Salisbury, K. 2018. Vielversprechende Ansätze und kleine Irrwege: die Interpretationsgeschichte frühbronzezeitlicher Bestattungen am Beispiel Schleinbach, pp. 45-56 in Pieler, F. and Trebsche, P. (eds.), Beiträge zum Tag der Niederösterreichischen Landesarchäologie 2018. Asparn: Niederösterreichisches Landesmuseum.

Rebay-Salisbury, K., Pany-Kucera, D., Spannagl-Steiner, M., Kanz, F., Galeta, P. and Salisbury. R. B. 2018. Motherhood at Early Bronze Age Unterhautzenthal. Archaeologia Austriaca 102: 71-134

Reiter, V. 2008. Frühbronzezeitliche Brandbestattungen im Unteren Traisental, Niederösterreich. Fundberichte aus Österreich 47, 195-234.

Rettenbacher, M. 2004. Die Siedlung und die Gräberfelder von Schleinbach: Eine Studie zur Aunjetitz-Kultur im südlichen Weinviertel (Archäologische Forschungen in Niederösterreich 2). St. Pölten: Niederösterreichisches Institut für Landeskunde.

Rittershofer, K.-F. 1987. Grabraub in der Bronzezeit. Bericht der 
Römisch-Germanischen Kommission 68, 5-23.

Rottier, S., Mordant, C., Chambon, P. and Thevenet, C. 2005. Découverte de plus d'une centaine de sépultures du Néolithique moyen à Gurgy, les Noisats (Yonne). Bulletin de la Société Préhistorique Française 102/3, 641-5.

Sayer, D. and Dickinson, S. D. 2013. Reconsidering obstetric death and female fertility in Anglo-Saxon England. World Archaeology 45, 285-97.

Spannagl-Steiner, M., Novotny, F. and Teschler-Nicola, M. 2011. Blickpunkt Mensch. Bevölkerungsbiologische Untersuchungen der Populationsgemeinschaft von Hainburg/Teichtal. Archäologie Österreichs 22, 27-32.

Spannagl-Steiner, M., Novotny, F., Pany-Kucera, D., RebaySalisbury, K. and Teschler-Nicola, M. 2016. Accidental versus Intentional Head Injuries: A Comparative Pilot-Study of Cranial Depressed Fractures. Poster presented at the 21st European Meeting of the Paleopathology Association, Research Institute and Museum of Anthropology, Moscow.

Sprenger, S. 1999. Zur Bedeutung des Grabraubes für sozioarchäologische Gräberfeldanalysen. Eine Untersuchung am frühbronzezeitlichen Gräberfeld Franzhausen I, Niederösterreich. Fundberichte aus Österreich, Materialheft A 7. Wien: Berger.

Szombathy, J. 1929. Prähistorische Flachgräber bei Gemeinlebarn in Niederösterreich (Römisch-Germanische Forschungen 3). Berlin: De Gruyter.

Szombathy, J. 1931. Kleinwüchsige Skelette aus bronzezeitlichen Gräbern bei Gemeinlebarn. Mitteilungen der Anthropologischen Gesellschaft in Wien 61, 1-28.

Sørensen, M. L. S. 2013. Identity, gender, and dress in the European Bronze Age, pp. 216-33 in Fokkens, H. and Harding, A. (eds.), The Oxford Handbook of the European Bronze Age. Oxford: Oxford University Press.

Teschler-Nicola, M. 1994. Bevölkerungsbiologische
Aspekte der frühen und mittleren Bronzezeit, pp. 16783 in Neugebauer J.-W. (ed.), Bronzezeit in Ostösterreich. Wissenschaftliche Schriftenreihe Niederösterreich 98-101. St. Pölten-Wien: Niederösterreichisches Pressehaus.

Teschler-Nicola, M. and Prossinger, H. 1997. Aspekte der Paläodemographie anhand der frühbronzezeitlichen Friedhöfe des Unteren Traisentales (Franzhausen I, Franzhausen II, Gemeinlebarn F und PottenbrunnRatzersdorf), pp. 43-57 in Rittershofer, K.-F. (ed.), Demographie der Bronzezeit. Paläodemographie - Möglichkeiten und Grenzen (Internationale Archäologie 36). Espelkamp: Marie Leidorf.

Ubelaker, D. H. and De La Paz, J. S. 2012. Skeletal Indicators of Pregnancy and Parturition: a historical review. Journal of Forensic Science 57, 866-72.

Weiss-Krejci, E. 2001. Restless Corpses. 'Secondary burial' in the Babenberg and Habsburg Dynasties. Antiquity 75, 76980.

Weninger, J. 1954a. Frühbronzezeitliche Skelette aus Schleinbach in Niederösterreich. Teil 1: Eine seltsame Mehrbestattung aus Schleinbach (N.-Ö.) Archaeologia Austriaca 16, 1-27.

Weninger, M. 1954b. Frühbronzezeitliche Skelette aus Schleinbach in Niederösterreich. Teil 2: Die Einzelbestattungen aus Schleinbach (N.-Ö.) Archaeologia Austriaca 16, 28-66.

Wewerka, B. 1982. Ein frühbronzezeitliches Gräberfeld aus Zwingendorf, Niederösterreich. Archaeologia Austriaca 66, 21-47.

Wiltschke-Schrotta, K. 1988. Das frühbronzezeitliche Gräberfeld von Franzhausen I: Analyse der Morphologischen Merkmale mit Besonderer Berücksichtigung der Epigenetischen Varianten. Unpublished PhD thesis, Universität Wien. 